\title{
The Cultivation of Cultural Connotation in College English Teaching about the Sun Also Rises
}

\author{
Dongmei Sheng \\ Foreign Language Department, Jilin Business and Technology College, Changchun, China \\ 455635403@qq.com
}

Keywords: Culture; Connotation; College English teaching; Personal value

\begin{abstract}
The aim of this study is to cultivating students' ability to use language and improving the cultural quality .This paper presents the educational function of College English teaching and puts forward to change the current situation of colleges by firming teachers' literature beliefs, focusing on improving teachers' own literature quality. At the same time, this paper also advocates teaching method application, learning mode, reading curriculum evaluation in the classroom and outside of the classroom. The result shows that putting the literature education into College English classroom is beneficial for cultivating the students' cultural ability. The result suggests that the better teaching method in college students' literature class is of great significance in improving college students' cultural quality.
\end{abstract}

\section{Introduction}

The relationship between language and culture is subtle. On the one hand, language is the carrier of culture and people understand foreign culture by listening and reading foreign language. On the other hand, there is no certain knowledge of exotic culture and it is difficult to understand a foreign language in exotic culture. Because of this delicate relationship, in teaching foreign language the teachers need to strengthen the language teaching, at the same time teachers also need to help students clear cultural barriers, revealing the cultural capacity, which is the aim of learning the language and achieving unity of the upbringing and education. Of course, for the exotic culture, teachers can only coach and dredge rather than only teach the language points outside of the class.

Hemingway's work is concise and fluent containing rich and profound known. He tells the story of " the sun also rises is no exception. Simple words make the theme clear and the theme is to express the personal value, which is not difficult to understand. Then, what is the implication of this story? The answer will have different views. The author believes that the discussion of this problem cannot be without the understanding of the differences between Chinese and Western culture. From the perspective of Chinese and Western culture, we could understand the aspects of the huge difference. The basis of western writers comes from their own culture and perspective. Our Chinese readers read their books on the basis of essential knowledge of western culture. We need have insight into previously unknown western culture and consider its cultural value. Otherwise we will not understand the works and even misunderstand them. The sun also rises involves how to raise the education of future generations. To deal with this problem, the dominant view of Chinese and Western are different.

In 1926, "The Sun Also Rises" appeared in the public, with which Hemingway became the voice of "the Lost Generation" and the prominent writer of his time. "The Sun Also Rises" is Hemingway's first novel among his works. The characters in this novel have different personalities and intricate relationships among them. These kinds of characters are like Hemingway's shadow and they are the "lost generation", which reflect Hemingway's thoughts and understanding of life.

It describes a group of youth, who lingered in Paris, drank and danced all days. They wandered in boxing, fishing and watching bull-fighting. The First Word War broke their dreams. When they came back from the front, they felt perplexed. They had experienced the suffering given by the war and felt that they had lost everything, wouldn't go to college, wouldn't go to work. Sometimes they quarreled with each other, sometimes they fought in a love triangle. There are no thrilling and 
fantastic plots in it. The short sentence and concise words displayed the continuous and vivid pictures one by one. When I first read it, I was confused by the exchanges of paces. They drank the beer here, and then dance there. But just this straight forward style of writing had revealed the different characters of the figures.

\section{Understanding Different Characters}

There are 16 characters who appeared in succession in the sun also rises, strictly speaking, which includes only four, Jack Barnes, Robert Cohen, Robert Cohn, Brett Ashley and Pedro Romero. These characters exit in the real society. According to their prototype, Hemingway had disintegrated and then added to the imagination to restructure and confer the new life. So these characters are all alive.

\section{Description of Jack}

Jack, the narrator and the model of character who is defeated, appeared in the first person and is created by Hemingway according to his own experience. He took part in the First Word War and unfortunately, he was wounded and became sexually impotent. In the hospital, he met Brett, a beautiful and lovely girl. They fell in love quickly and deeply. Because Jake was impotent, they couldn't marry. So the lovers had to separate with each other. In Paris, they met again, but everything changed. Jake ever longed for the happy day to come, but the war smashed his dream. He came into group with other youth, who had the same feeling for the war. The only thing they were willing to do was to forget all the past, forget the suffering. The author told this in a plain way. What we saw was so many bottles and so many drunken men. Jake had to force himself to give up his love. In the day, he mixed with his friends, at night he fell into deep pain. "I was thinking about Brett...I started to cry" Jack and Brett were both painful especially when they met together. The hurting from the war had not only influenced the body, but also his spirit. Their suffering was imaginable.

Jake was always sleepless at night, while Brett often went into drunk. The wound built a wall between them. They stood by the two sides of wall, tearing in heart. Jake wanted to escape from the reality. He devoted himself in fishing, watching the bull-fighting, but once he met Brett, he had to control himself. The more he loved, the more he suffered. Before Brett, he became a loyal friend of Brett, and maintained his composure to help Brett, although some actions were out of his willingness. People often said that love was selfish. To Jake love was gentle. He spared no effort in satisfying Brett. Especially when Brett began to like Romero, Jake introduced Brett to Romero. When Brett was in trouble, a telegram led Jake to the Brett's side. His feeling existed in spirit. Brett's happiness was equal to his happiness; Brett's sadness was equal to his sadness.

\section{Description of Brett}

Brett was also the victim of the war. Her lover died in the war. Then she met Jake in the hospital. Her first love was destroyed by the war; her second one was destroyed by the war too. The war made her meet Jake. The war also hindered their unity. She was tortured by fate very much. Everything seemed valueless to her. She married twice, and then divorced. She lived together with any man she liked and became the new image of the postwar. Jake was a lively man, but he had no ability to many her. Was there any difference between the dead man and Jake? Maybe God played a joke with her. In order to escape from the cruel reality, she walked in a lost way, contradictory with the traditional moral. In other's eyes, she was a lost woman and many men circled around her, accompanying her to travel. But in her internal heart, she loved Jake so much. The reality forced her to escape. The description of her eyes showed that: "She looked as though there were nothing on earth she would not look at like that, and really she was afraid of so many things".

The flare of her love was put off gradually by the war. Although her action runs into an opposite way, she still kept her kind mood. When Romero made an offer of marriage, Brett refused him and 
drove him away. In the end, Brett wanted to have a peaceful life and correct her errors and make a fresh start.

\section{Description of Cohn}

Among the suitors of Brett, Cohn was the most selfish one. Even at some time, he lost the respect as a real man should have. Mike insulted him several times, but he still circled around Brett, saying nothing. His love made Brett tire. Cohn had lost his own personality and his own careers for seeking for his so-called true love.

\section{Description of Romeno}

As the winner of seeking Brett, Romeno was the symbol of completeness. His grace in the bull-ring wined all people's appreciation including Brett. She was charmed by his temper skill and spirits . Romero didn't care about his wound in body and went back to the bull ring again with vigorousness and energy. He shouted at the audience the special "grace under pressure" belonging to the bull-fighters. The death accompanied him all the time in bull-ring. The bull would kill him very quickly and easily. In fact, he fought with the bull, just like fighting with the death. His pressure came from the death directly, while Jake's pressure comes from the internal invisible pain, which couldn't be expressed by words. He tried his best to live a common life.

When he was free, he would invite his friends to have a dinner or go to dance. His wound was mentioned a little in a plain way. In the reader's eyes, he had no difference with common people. The pain had been hidden in his heart. In the day, he mixed with his friends, only at night he stayed up all the time. Just as it was said in the text book, "The only strength to live on with a dignity with grace under pressure" He was Hemingway's hero who appeared as an unyielding man. From him the Hemingway's theme was showed to us.

\section{Discussion}

Thus, in this story that Hemingway did not deliberately belittle the little figure and does not create a heartless image. He just followed the Western point of view, which is his own opinion, and truthfully reflects the Western relevant cultural information. Maybe we can "read" this information and maybe we have not been able to "read" this information. There should be other ways to do more to understand western culture and make a comment. It seems we should not rush to use their cultural perspective to explain that. The structure of this novel is formed by a series of four places: Paris, Pyrenees, Pamplona and Saint-Perth Dian, each with specific meaning. After the First World War, all business in Paris languishes, except bar industry. At this time, main characters appeared, who are Jack Barnes, Robert Cohen, Robert Cohn, Brett Ashley and Pedro Romero .Jack was the axle of the wheel emitting many Round bar connected with them. Because he is a reporter, owning an objective observation, so his pen described the scene of young people wandering the streets including the writer himself from one bar to another, playing from one party to another, doing nothing, seeking pleasure. Paris became the Hemingway's wilderness.

In real life, not all the persons could keep the grace under pressure. When confronting some pressure from life or work, someone became pessimistic and depraved, even became murderous. Most of persons lost confidence of living, and then gave up their own struggle with fate, waiting for help from government or begging from door to door. On the contrary, on the maimed person's sport meeting, we saw so many vigorous disabled persons promising and diligent in their work. Their graceful bearing was admired by all people in the world. Truly speaking, everyone who lives in world will burden the different pressure more or less, no mater who he is, rich or not. Some chose to escape, they drank all day and all night, but alcohol only could anesthetize a short time. After coming back to wake up, they had to face the reality. The sun wouldn't stop because of your sadness. The sun also rises from the east life is so much? 


\section{Conclusion}

Cultural connotation is a kind of intrinsic and comprehensive literature appreciation and creative quality. It is a process of gradual accumulation, which is not easy to accomplish in one step. In the highly developed material civilization of modern society, people's attitude is more and more impetuous. The blind pursuit of fashion, lack of thinking, lack of precipitation including the college student .Therefore, in College English teaching teachers should establish a firm belief in the literature education, good at exploring literary elements in the text mining, seizing the opportunity of cultivating students cultural connotation, enhancing students' literary accomplishment and making the students into healthy noble spirit of people.

\section{References}

[1] Hemingway Earnest. Fiesta: The Sun Also Rises (London: Vintage Books, 2000)

[2] Bressler Charles E. Literary Criticism - an Introduction to Theory and Practice (Beijing: Higher Education Press, 2004)

[3] Crowley John W. The White Logic: Alcoholism and Gender in American Modernist Fiction (Amherst: University of Massachusetts Press, 1994)

[4] Davidson Arnold E. and Cathy N. New Essays on the Sun Also Rises (Cambridge: The Press of the University of Cambridge, 1987. 83-108)

[5] Dollimore, Jonathan. Sex, Literature and Censorship (Cambridge: Polity Press, 2001)

[6] Freud Sigmund. Beyond the Pleasure Principle (the standard edition) (James Strachey (Trans.). New York: Liveright Publishing Corporation, 1961)

[7] Freud Sigmund. Civilization, Society and Religion: Group Psychology (London: Penguin, 1991)

[8] Hart, Jeffrey. The Sewanee Review, 1978(4): 557-562.

[9] Adair, William. ANQ: A Quarterly Journal of Short Articles, 2010, 23, (4): 243-249.

[10]Bradley, Jacqueline. The Explicator, 64:4 (2006: Summer): 231. 